DOI: $10.21802 /$ artm.2020.3.15.92.

УДК 616.346.2-002.1-053-037-089:616-008.6

\title{
ІНТЕГРАЛЬНА ОЦНКА ЕНДОГЕННОЇ ІНТОКСИКАЦІЇ ОРГАНІЗМУ В ПРОГНОЗУВАННІ ФОРМ ПЕРЕБІГУ ГОСТРОГО АПЕНДИЦИТУ У ДІТЕЙ
}

\author{
В.С. Конопліцький, Ю.С. Коробко, В.В. Мотигін
}

Вінницький наиіональний медичний університет імені М.I. Пирогова, кафедра дитячої хірургї̈,
м. Вінниия, Украйна,
ORCID ID: 0000-0001-9525-1547, ORCID ID: 0000-0002-3299-878X,
ORCID ID: 0000-0002-2494-1716, e-mail: vkonoplytsky@gmail.com

Резюме. Стаття присвячена дослідженню особливостей гемограми при різних формах гострого апендициту на основі вивчення індексів ендогенної інтоксикації організму. Проведені дослідження периферійної

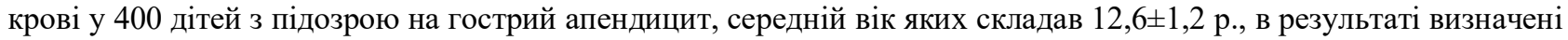
достовірні відмінності між різними інтегральними показниками ендотоксикозу організму, а саме індексу співвідношення лейкоцитів і швидкості осідання еритроцитів та індексу зсуву лейкоцитів, які враховують всі чинники гемограми.

Метою роботи була розробка інтегрального індексу інтоксикації організму при гострому апендициті у дітей та прогнозування на його основі різних форм ускладненого перебігу захворювання з урахуванням показників розширеного загального аналізу периферійної крові.

Інтегральний підхід до інтерпретації показників ендогенної інтоксикації за даними гемограми на основі величини сумарного індексу ендогенної інтоксикації дозволяє оцінити виразність ендотоксемії, на основі якої можливо спрогнозувати наявну форму патології та своєчасно обрати необхідну лікувальну тактику. Перевищення величини запропонованого сумарного індексу ендогенної інтоксикації організму більше, ніж в два рази засвідчує у дитини наявність рівня ендотоксикозу, характерного для деструктивних форм гострого апендициту, перевищення індексу більше, ніж в 2,5 рази вказує на можливий ускладнений перебіг патології у вигляді перитоніту. Введення розробленого сумарного індексу ендогенної інтоксикації в алгоритм гострого апендициту дозволить покращити результати ранньої діагностики патології та її перебіг у дітей.

Ключові слова: діти, гострий апендицит, ендогенна інтоксикація, індекс.

Вступ. Точність діагностики гострого апендициту (ГА) залишається важливою проблемою сучасної клінічної хірургії дитячого віку. Діагностика ГА у дітей ускладнена через значні анатомічні відмінності та фізіологічні особливості дитячого організму, що призводить до затримки термінів хірургічного лікування та відповідно до підвищеного ризику розвитку ускладнень [1].

Крім того, диференційна діагностика патологічних процесів, які симулюють ГА, в деяких випадках являє собою велику проблему, особливо у дітей молодшої вікової групи $[2,3,4]$.

3 метою інтегральної оцінки клінічних та лабораторних ознак при гострих запальних процесах в черевній порожнині, фахівцями хірургічного профілю для стратифікації пацієнтів було запропоновано ряд так званих діагностичних шкал (ДШ), в тому числі для діагностики ГА, такі як Alvarado, Lindberg, Fenyo, Christian, Eskelien та ін. [5]. Однак систематизований огляд 14 ДШ ГА (2013), в якості найбільш об'єктивних та роботоспроможних визначив ДШ Alvarado, Fenyo та Eskelien за умов комплексної оцінки лабораторних даних та додаткових клінічних візуальних методів дослідження [6, 7]. У педіатричній практиці запропонована ДШ Lintula, чутливість якої, за даними рандомізованого дослідження, склала 87\%, специфічність - 59\% та точність - 74\% [8]. Крім того, ургентне визначення показників, які входять до ДШ, не завжди доступне, що пов'язано з можливостями лабораторних підрозділів медичних закладів, тривалістю досліджень та оцінкою їх результатів в бальній системі, які іноді є досить суб'єктивними.

Лише клінічні прояви симптомокомплексу ендогенної інтоксикації (ЕI) малоспецифічні, в тому числі при ГА, а визначення інтегральних показників ендотоксикозу дозволяє оцінити стан хворого, не залучаючи спеціальні методи дослідження, за даними загального клінічного аналізу крові, особливо при його математичному моделюванні [9]. Водночас проблема застосування лабораторних досліджень крові в діагностиці ГА полягає в їх низькій специфічності та чутливості [10].

Розробка достеменного та доступного алгоритму діагностики ГІ, в тому числі з урахуванням інтегральних показників гемограми, який би дозволив в короткі терміни вирішити питання про доцільність виконання апендектомії, залишається актуальною та до цього часу не вирішеною проблемою дитячої хірургії.

Обгрунтування дослідження. У процесі філогенезу у людини сформувалась важлива базова біологічна функція - ендоекології (забезпечення "чистоти" внутрішнього середовища організму), яка згідно з сучасними уявленнями підтримує гомеостаз на молекулярному рівні, обмежуючи перевищення 
меж будь-яких метаболітів та фізико-хімічних параметрів [11].

Реалізація функції ендоекології відбувається за рахунок двох неспецифічних біологічних реакцій: екскреції та запалення. При перевищенні величин біологічно активних частинок в 70 кД (межа для проходження через нефрон), до утилізації метаболітів долучаються клітини пухкої сполучної тканини (нейтрофіли, макрофаги, ендотеліальні клітини). Перша ланка такого механізму - сегментарні нейтрофіли мають рецептори для ідентифікації патогенів, через що реакції гранулоцитарної системи вважаються неспецифічними, так як можуть розвинутись у відповідь на різноманітні інфекційні (віруси, бактерії та їх токсини) і неінфекційні (фізичне навантаження, травма, гіпоксія, стрес) фактори. Зважаючи на цей факт, будь-які лейкоцитарні індекси необхідно розглядати лише у якості клітинних маркерів реактивності гранулоцитарної системи, які в деяких випадках не відображають наявність ЕI, особливо при зменшенні їх рівнів нижче середньо визначених величин $[11,12]$.

Це характерно для розвитку ГА, при якому надлишкове утворення метаболітів не завжди має лавиноподібний характер, а ЕI може мати латентний перебіг, але 3 високим навантаженням на системи елімінації, що важко визначити на ранніх стадіях розвитку патології та спрогнозувати ії перебіг в подальшому лише по змінах в лейкограмі [12].

Ендогенна інтоксикація, як будь-який токсикоз - це каскадний, стадійний, схильний до прогресування генералізований процес, зумовлений накопиченням в кров'яному руслі токсичних речовин у концентраціях, які перевищують функціональні можливості природних систем детоксикації 3 подальшим пошкодженням інших органів та систем організму. При цьому одним із органів мішеней $\epsilon$ кістковий мозок, в якому при наявності ЕІ подразнюються одночасно червоний та білий його паростки, що проявляється певними змінами в гемограмі. Аналіз складових гемограми в динаміці перебігу запального процесу у інтегральному обчисленні дозволить моніторити наявність ГА у дітей.

Мета дослідження: розробка інтегрального індексу інтоксикації організму при гострому апендициті у дітей та прогнозування на його основі різних форм ускладненого перебігу захворювання з урахуванням показників розширеного загального аналізу периферійної крові.

Матеріали і методи. Всього в дослідження було долучено 400 осіб, які були розділені на 4 групи, по 100 дітей: I група - практично здорові діти; II група - пацієнти, госпіталізовані у хірургічне відділення 3 абдомінальним больовим синдромом, у яких, за результатами клініко-лабораторних досліджень, в динаміці патології не було виявлено; III група - пацієнти, оперовані $з$ приводу деструктивних форм ГА, перебіг якого не був ускладнений перитонітом; IV група - пацієнти, оперовані з приводу деструктивних форм ГА, перебіг якого був ускладнений перитонітом різної поширеності. Діти із катаральними формами
ГА в дослідження не залучались. Середній вік пацієнтів склав $12,6 \pm 1,2$ років.

Критерієм для включення у вибірку була письмова добровільна згода батьків пацієнта та наявність технічної можливості провести весь комплекс дослідницьких заходів при госпіталізації.

Проведено аналіз гематологічних показників крові у всіх пацієнтів чотирьох груп дослідження (індексу співвідношення лейкоцитів і ШОЕ (ICЛШОЕ) та індексу зсуву лейкоцитів (IЗЛ) за Н. I. Ябучинським). Зразки крові на дослідження брали безпосередньо при госпіталізації паціснтів на стаціонарне лікування. Дослідження крові проводили стандартними методами: ШОЕ мікрометодом Т.П. Панченкова, підрахунок кількості лейкоцитів у камері Н.К. Горяева, імерсійна диференційна мікроскопія забарвлених мазків крові на бінокулярному мікроскопі.

Розрахунок ІСЛШОЕ проводили за формулою $І С Л Ш О Е=\frac{(Л \times Ш O E)}{100}$, де: Л - кількість лейкоцитів; ШОЕ - швидкість осідання еритроцитів. А розрахунок ІЗЛ проводили за формулою IЗЛ $=\frac{(e+\sigma+n+c+ю+м u)}{(м о н+л і м)}$, де е - еозинофіли; б базофіли; п - паличкоядерні нейтрофіли; с - сегментоядерні нейтрофіли; мц - мієлоцити; мон - моноцити; лім - лімфоцити [13].

Для оцінки достовірності зроблених висновків відносно різниць порівнюваних вибірок в роботі обчислювались похибки визначення середніх $-\boldsymbol{m}$, які рекомендовані статистичною теорією оцінювання. Ці ж оцінки $\boldsymbol{m}$ використовувались в дослідженні для підтвердження достатності об'єму вибірки вимірювання. Кількість спостережень вважали достовірною при значенні середньоквадратичного відхилення $(\mathrm{p}<0,05)$.

Результати дослідження. Внаслідок дії специфічних збудників та факторів запалення при запальних захворюваннях причиною лейкоцитозу є стимуляція лейкопоетичної функції кровотворних органів, що зумовлює клініку хвороби. У дітей молодшої вікової групи кількість лімфоцитів з віком зменшується при одночасному збільшенні нейтрофілів, і з 46 років на тлі збільшення числа нейтрофілів продовжує зменшуватись кількість лімфоцитів, і продовжується цей процес до початку підліткового періоду.

Щодо рівня лейкоцитів периферійної крові, то їх референтна кількість в нормі має певну тенденцію до змін, а саме зменшення їх кількості із віком, від $6,0-17,5 \times 10^{9} /$ л в 1 рік і до $4,5-10,0 \times 10^{9} /$ л в 16 років, досягаючи "дорослих" показників у віці 18-21 рік. Крім того, термін "лейкоцитоз" має більш багатогранне трактування, ніж «... збільшення загальної кількості лейкоцитів периферійної крові більше середнього рівня норми», щодо якого в своїй класифікації влучно висловилися О.В. Николаева та співавт., (2016) (рис. 1) [14]. 


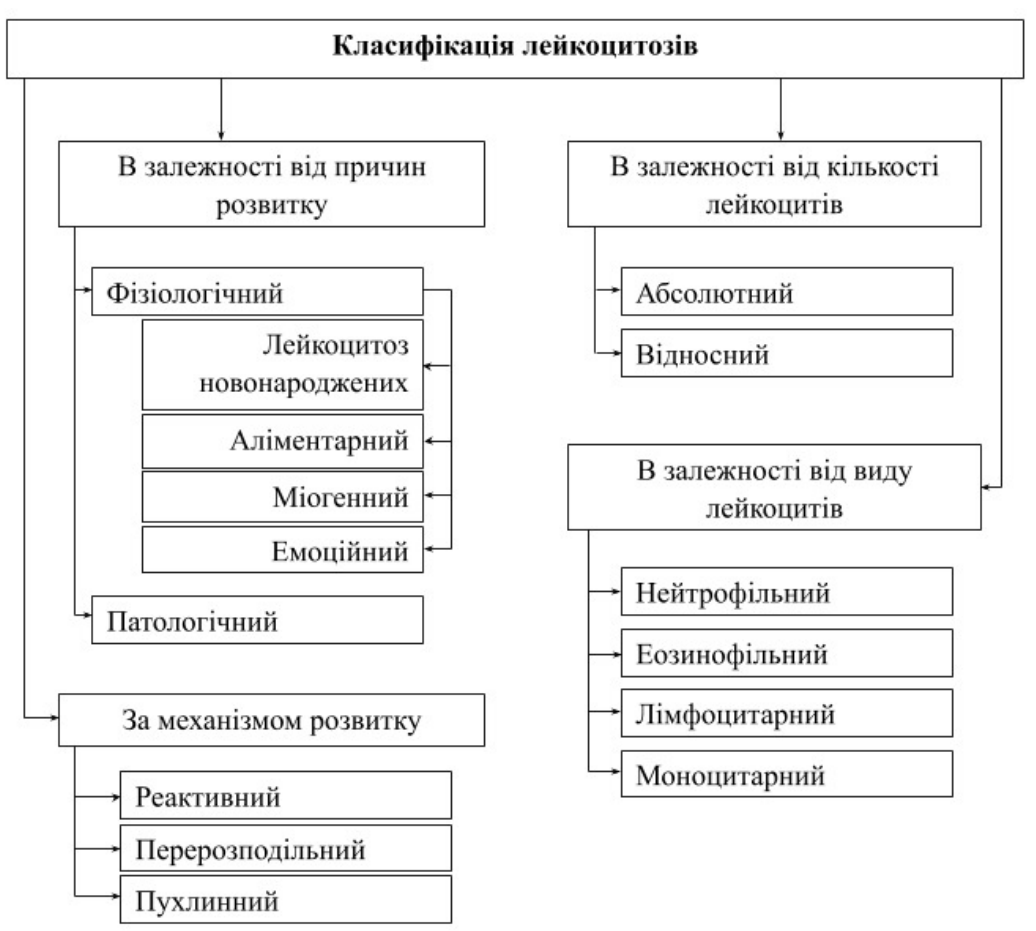

Рис. 1. Класифікація лейкоцитозів

При гострих запальних процесах зміна ШОЕ спостерігається через 24 години після початку гіпертермії та збільшення кількості лейкоцитів. Зменшення кількості еритроцитів крові призводить до прискорення ШОЕ, а збільшення, відповідно, сповільнює швидкість седиментації.

Щодо змін лейкограми, то підвищення сумарного відсоткового вмісту нейтрофілів понад норму у
Водночас будь-яка орієнтація тільки на число лейкоцитів достатньо ненадійна, через часту неадекватну реакцію на інфекцію, яка пов'язана з віком, статтю, тривалістю інфекційного процесу, наявністю супутньої патології та ін. [14]. За даними групи російських авторів, наявність лейкоцитозу $>10 \times 10^{9} /$ л при наявності інших клінічних проявів ГА, в діагностичному аспекті має чутливість лише 85\% при специфічності 74\% [15].

Другим лабораторним клінічно-значимим показником гемограми є ШОЕ - неспецифічний показник запалення, величина якого залежить від багатьох фізіологічних та патологічних факторів, статі, тривалості безпосереднього проведення дослідження (осідання еритроцитів відбувається в три фази, які мають різну швидкість), пори доби, білкового складу плазми (гострофазні білки прискорюють ШОЕ). кожного хворого свідчить лише про можливість розвитку в організмі запального процесу.

Тому на першому етапі реалізації мети нашого дослідження нами вивчалась динаміка рівнів ICЛШОЕ та ІЗЛ для визначення їх спроможності в якості маркерів ЕI при різних формах ГА у дітей.

Таблиця 1

Величини ІСЛШОЕ та ІЗЛ при госпіталізації у пацієнтів усіх груп порівняння

\begin{tabular}{|c|c|c|c|c|c|c|c|}
\hline \multirow{2}{*}{$\begin{array}{c}\text { Показники } \\
\text { ЕI організму } \\
\text { (ум. од.) }\end{array}$} & Норма & $\begin{array}{c}\text { При підозрі } \\
\text { на ГА }\end{array}$ & \multirow[t]{2}{*}{$\mathrm{p}$} & $\begin{array}{c}\text { ГА без пери- } \\
\text { тоніту }\end{array}$ & \multirow[t]{2}{*}{$\mathrm{p}$} & $\begin{array}{c}\text { ГА + } \\
\text { Перитоніт }\end{array}$ & \multirow[t]{2}{*}{$\mathrm{p}$} \\
\hline & $\mathrm{n}=100$ & $\mathrm{n}=100$ & & $\mathrm{n}=100$ & & $\mathrm{n}=100$ & \\
\hline ІСЛШОЕ & $0,32 \pm 0,01$ & $1,13 \pm 0,15$ & $<0,05$ & $1,29 \pm 0,14$ & $<0,05$ & $2,19 \pm 0,32$ & $<0,05$ \\
\hline ІЗЛ & $2,52 \pm 0,1$ & $3,48 \pm 0,51$ & $>0,05$ & $5,76 \pm 0,89$ & $<0,05$ & $5,46 \pm 0,48$ & $<0,05$ \\
\hline
\end{tabular}

Отримані дані довели той факт, що динаміка аналізованих показників мала позитивний приріст в усіх групах дослідження, який свідчив про їх спроможність в якості маркерів ендотоксикозу в перебігу ГА у дітей.

Беручи до уваги отримані дані та інформаційні повідомлення інших дослідників, нами запропоновано інтегральний сумарний індекс ендогенної інтоксикації (CIEI), в якому були враховані всі складові гемограми, і який обраховували за формулою:
$C I E I=\frac{I C Л Ш O E+I 3 Л}{2}=\left(\frac{(Л \times \amalg O E)}{100}+\frac{(e+\sigma+n+c+ю+м u)}{(м о н+\pi i м)}\right) / 2$, де: Л - кількість лейкоцитів; ШОЕ - швидкість осідання еритроцитів; е - еозинофіли; б - базофіли; п паличкоядерні нейтрофіли; с - сегментоядерні нейтрофіли; мц - мієлоцити; мон - моноцити; лім - лімфоцити; CIEI в нормі складає в середньому 1,42 $\pm 0,06$ ум. од.

Дослідження розрахункових величин CIEI при різних формах патології чітко визначило наявність позитивно спрямованої динаміки (табл. 2).

Таблиця 2

Величина СІЕІ при госпіталізації у паціснтів всіх груп порівняння

\begin{tabular}{|c|c|c|c|c|c|c|c|}
\hline \multirow{2}{*}{$\begin{array}{c}\text { Сумарний } \\
\text { показник } \\
\text { ЕI організму }\end{array}$} & Норма & $\begin{array}{c}\text { При підозрі } \\
\text { на ГА }\end{array}$ & \multirow[t]{2}{*}{$\mathrm{p}$} & $\begin{array}{c}\text { ГА без пери- } \\
\text { тоніту }\end{array}$ & \multirow[t]{2}{*}{$\mathrm{p}$} & $\begin{array}{c}\text { ГА + } \\
\text { перитоніт }\end{array}$ & \multirow[t]{2}{*}{$\mathrm{P}$} \\
\hline & $\mathrm{n}=100$ & $n=100$ & & $\mathrm{n}=100$ & & $\mathrm{n}=100$ & \\
\hline CIEI (ум. од.) & $1,42 \pm 0.06$ & $2,31 \pm 0,32$ & $<0,05$ & $3,52 \pm 0,45$ & $<0,05$ & $3,80 \pm 0,31$ & $<0,05$ \\
\hline
\end{tabular}


Наявність такої позитивної динаміки CIEI вказує на наявність та збільшення величини EI при зростанні явищ тканинної деструкції, що розцінене в якості прямої ознаки автоінтоксикації.

Обговорення результатів. Таблиця 1 наглядно відображає збільшення в 3,53 рази величини ICЛШОЕ в II групі відносно I групи (відповідно $1,13 \pm 0,15$ ум. од. проти $0,32 \pm 0,01$ ум. од. $(\mathrm{p}<0,05)$; в

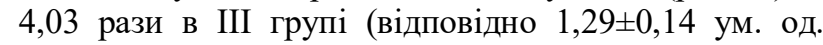
проти $0,32 \pm 0,01$ ум. од. $(\mathrm{p}<0,05)$; в 6,84 рази в IV гру-

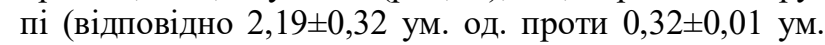
од. $(\mathrm{p}<0,05)$.

Практично аналогічна динаміка визначена при аналізі величини І3Л, а саме збільшення в 1,38 рази величини показника в II групі відносно до норми

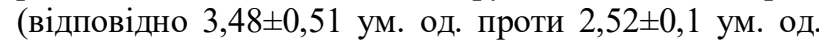
( $>0,05)$; в 2,29 рази в III групі (відповідно 5,76 $\pm 0,89$ ум. од. проти $2,52 \pm 0,1$ ум. од. $(\mathrm{p}<0,05)$; в 2,17 рази в IV групі (відповідно 5,46 $\pm 0,48$ ум. од. проти $2,52 \pm 0,1$ ум. од. $(\mathrm{p}<0,05)$.

Така суттєва позитивна динаміка показників ICЛШОЕ та ІЗЛ як маркерів ЕІ при ГА у дітей була характерною і для запропонованого інтегрального CIEI.

В II групі пацієнтів величина CIEI була збільшена лише в 1,63 рази порівняно з групою контролю (відповідно 2,31 $\pm 0,32$ ум. од. проти $1,42 \pm 0,06$ ум. од. $(\mathrm{p}<0,05)$.

В III групі величина CIEI була більшою у 2,48 рази за рівень показника I групи порівняння (відповідно 3,52 $\pm 0,45$ ум. од. проти $1,42 \pm 0,06$ ум. од. $(\mathrm{p}<0,05)$.

B IV групі рівень CIEI перевищував вже в 2,68 рази величину показника в I групі порівняння

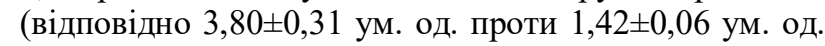
$(\mathrm{p}<0,05)$.

Отримана динаміка інтегрального CIEI клінічно корелювала із даними проведених інструментальних досліджень та інтраопераційних знахідок.

Більше, ніж двократне збільшення величини CIEI в III та IV групах засвідчує високий ступінь активності запального процесу (рис. 2).

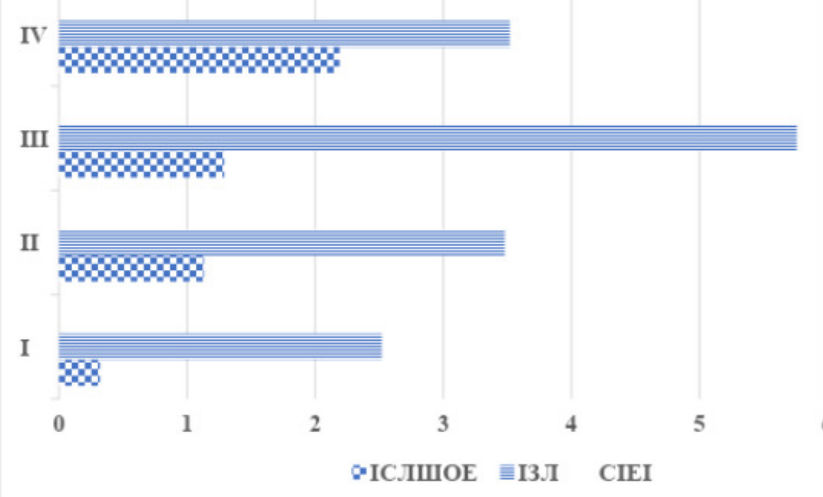

Рис. 2. Діаграма показників ЕІ при госпіталізації в усіх групах порівняння

Висновки. При ускладненому перебігу гострого апендициту вогнище інфекції є однією із основ- них причин у виникненні та розвитку EI, рівень якої пов'язаний із важкістю тканинного руйнування. Інтегральний підхід до інтерпретації показників EI за даними гемограми на основі величини CIEI дозволяє оцінити виразність ендотоксемії, на основі якої можливо спрогнозувати наявну форму патології та своєчасно обрати необхідну лікувальну тактику. Перевищення величини запропонованого сумарного індексу EI організму більше, ніж в два рази засвідчує у дитини наявність рівня ендотоксикозу, характерного для деструктивних форм гострого апендициту, перевищення індексу більше, ніж в 2,5 рази вказує на можливий ускладнений перебіг патології у вигляді перитоніту. Введення розробленого сумарного індексу ендогенної інтоксикації в алгоритм гострого апендициту дозволить покращити результати ранньої діагностики та певною мірою спрогнозувати форму патології та її перебіг у дітей.

\section{References:}

1. Keyzer C, Gevenois PA. Imaging of acute appendicitis in adults and children. Springer. 2016. Vol. 268. doi: 10.1007/978-3-642-17872-6.

2. Zatevahin II, Kirienko AI, Kubyishkin VA. Abdominalnaya hirurgiya. Natsionalnoe rukovodstvo. Kratkoe izdanie. Moskva: GEOTAR. Media. 2016. P.912.

3. Panasiuk AI, Shurygina IA, Byrgazov RO, Grigorev YG. Khronicheskii appenditsit. Opredelenie poniatiia, diagnostica i lechenie. Russian. Sklifosovskii J Emerg Med Care. 2016; 3:74-8.

4. Kaminskii MN, Vavrinchuk SA. Sravnitelnaia otsenka i optimizatsiia diagnosticheskih shkal ostrogo appenditsita. Molodoi uchenyi. 2017; 42:42-55.

5. Timerbulatov SV, Timerbulatov VM, Sagitov RV, Mekhdiev DI, Sakhautdinov RM. Ostryi Appenditsit: kliniko-laboratornye, laparoskopicheskie, patomorfo;ogucheskie peralleli. Creat Surg Oncol. 2019; 9(1):13-7. doi: 10.24060/2076-3093-2019-9-1-13-17.

6. Wilasrusmee C, Anothaisintawee T. Diagnostic scores for appendicitis: A systematic review of scores' performance. Br J Med Med Res. 2014; 4(2):711-30.

7. Lintula H, Pesonen E, Kokki H, Vanamo K, Eskelinen M. A diagnostic score for children with suspected Appendicitis. Langenbecks Arch Surg. 2005; 390(2):170. doi: 10.1007/s00423-005-0545-8, PMID 15723233.

8. Konoplitskyi VS, Motyhin VV, et al. Mathematical modeling for prediction of complicated acute appendicitis in children. Perioperaciina Med. 2018; 1:66-9. doi: 10.31636/prmd.v1i1.10.

9. Vakulchik VG, Statskevich SYu, Polityko DD. Analysis of the results of using the pediatric appendicitis score in the differential diagnosis of abdominal pain in children aged 5-17 years. J Pediatr Surg. 2019; 2(63):23-8. doi: 10.1557 4/PS.2019.63.23.

10. Sidelnikova VI, Chernitskiy AE, Retskiy MI. Endogennaya intoksikatsiia i vospalenie: posledovatelnost reaktsii i informativnost markerov. Selskohozyaystvennaia Biol. 2015; 50(2):152-61. 
11. Lee ACW. Diagnosing Infections from the peripheral Blood Smear. HK J Paediatr (new series). 2018; 23:25-8.

12. Çınar H, Aygün A, Derebey M, et al. Significance of hemogram on diagnosis of acute appendicitis during pregnancy. Ulus Travma Acil Cerrahi Derg. 2018; 24(5):423-428.

13. Tarasenko AV, Alekseev SA, Fedorov VN, Dudko AA. Evaluation of endogenous intoxication and necrotizing pancreatitis patients adverse out comes forecasting. Voennaia med. 2016; 2:59-62.

14. Sovtsov SA. Ostryi appenditsit. Klin Diagn Lech Cheliabinsk. 2016. P.196.

15. Razumovskiy AYu, editor. Detskaia khirurgiia. Nats. Rukovodstvo. IG "GEOTAR-media"; 2016. P.784.

УДК 616.346.2-002.1-053-037-089:616-008.6

ИНТЕГРАЛЬНАЯ ОЦЕНКА ЭНДОГЕННОЙ ИНТОКСИКАЦИИ ОРГАНИЗМА В ПРОГНОЗИРОВАНИИ ФОРМ ТЕЧЕНИЯ ОСТРОГО АППЕНДИЦИТА У ДЕТЕЙ

\section{В.С. Коноплицкий, Ю.С. Коробко, В.В. Мотигин}

Винницкий национальный медицинский университет имени Н.И. Пирогова (кафедра детской хирургии)

2. Винница, Украина,

ORCID ID: 0000-0001-9525-1547,

ORCID ID: 0000-0002-3299-878X,

ORCID ID: 0000-0002-2494-1716,

e-mail:vkonoplytsky@gmail.com

Резюме. Статья посвящена исследованию особенностей гемограммы при разных формах острого аппендицита на основе изучения индексов эндогенной интоксикации организма. Проведены исследования периферийной крови у 400 детей с подозрением на острый аппендицит, средний возраст которых составлял в $12,6 \pm 1,2$ г., в результате которых определены достоверные отличия между разными интегральными показателями эндотоксикоза организма, а именно индекса соотношения лейкоцитов и скорости оседания эритроцитов и индекса сдвига лейкоцитов, которые учитывают все факторы гемограммы.

Целью работы была разработка интегрального индекса интоксикации организма при остром аппендиците у детей и прогнозирования на его основании разных форм осложненного течения заболевания с учетом показателей расширенного общего анализа периферийной крови. Интегральный подход к интерпретации показателей эндогенной интоксикации по данным гемограммы на основании величины суммарного индекса эндогенной интоксикации позволяет оценить выразительность эндотоксемии, на основании которой возможно спрогнозировать имеющуюся форму патологии и своевременно избрать необходимую лечебную тактику. Превышение величины предложенного суммарного индекса эндогенной интоксикации организма больше чем в два раза удостоверяет у ребенка наличие уровня ендотоксикоза, характерного для деструктивных форм острого аппендицита.
Превышения индекса больше чем в 2,5 раза указывает на возможное осложненное течение патологии в виде перитонита. Введение разработанного суммарного индекса эндогенной интоксикации в алгоритм острого аппендицита позволит улучшить результаты ранней диагностики патологии и ее течение у детей.

Ключевые слова: дети, острый аппендицит, эндогенная интоксикация, индекс.

\section{UDC 616.346.2-002.1-053-037-089:616-008.6 INTEGRAL ESTIMATION OF ENDOGENOUS INTOXICATION OF ORGANISM IN PROGNOSTICATION OF THE FLOW ACUTE APPENDICITIS IN CHILDREN}

\author{
V.S. Konoplitskyi, Y.Ye. Korobko, V.V. Motyhin
}

National Pirogov Memorial Medical University,

department of pediatric surgery,

Vinnytsia, Ukraine,

ORCID ID: 0000-0001-9525-1547,

ORCID ID: 0000-0002-3299-878X,

ORCID ID: 0000-0002-2494-1716,

e-mail:vkonoplytsky@gmail.com

Abstract. Exactness of diagnostics of acute appendicitis remains an important problem of modern clinical surgery of child's age. Diagnostics of acute appendicitis in children is complicated by considerable anatomic differences and physiological features of the child's organism, which leads to delay of terms of surgical treatment and in accordance with an increase risk of development of complications.

In addition, the differential diagnostics of pathological processes that simulate acute appendicitis, on occasion shows a large problem, especially for the children.

The article is devoted to research of blood analysis in the different forms of acute appendicitis on the basis of study of indexes of endogenous intoxication in organism. Endogenous intoxication is caused by an accumulation in the blood toxiferous substances in concentrations, that exceed functional possibilities of the natural detoxication systems with the damage of other organs and systems of organism. The integral estimation of endogenous intoxication in humans organism is executed by mathematical method and consists of two indexes of intoxication. The first index (index of correlation of leucocytes and erythrocyte sedimentation rate) estimates general white blood cell count in blood and erythrocyte sedimentation rate. The second index (index of change of leucocytes) estimates the level of eosinophils, basophilies, all forms of neutrophils, lymphocytes and basophilies). If unite these indexes in one integral (total index of intoxication), then a result of estimation of intoxication of organism will be more precisely. The total index of intoxication estimates all indexes of general blood analysis that is appropriate in cases with suspicion on acute appendicitis.

In our research we conducted an examination of 400 children with suspicion on acute appendicitis. Middle 
age of patients was $12,6 \pm 1,2$. As a result of research considerable differences were found in the indexes of correlation leucocytes with erythrocyte sedimentation rate and index of change of leucocytes. The aim of our work was the development of total index of intoxication, that is estimates the more factors of blood test, than two previous separately. After the count of total index of intoxication it is possible more exactly to estimate the level of intoxication in organism at acute surgical pathology. Increase of total intoxication index more than in 2,5 times characteristic for the destructive forms of acute appendicitis. Introduction of total intoxication index in the algorithm of acute appendicitis will allow to improve the results of early diagnostics of pathology and its motion in children. At the complicated motion of acute appendicitis an infection is one of the main reasons in an origin and development of endogenous intoxication, the level of that is related to weight of tissue destruction. Integral approach of interpretation of indexes of endogenous intoxication from data of blood test on the basis of level of total index of intoxication allows to estimate expressiveness of endotoxemia. By a positive line, we have developed the total index of intoxication is simplicity and speed of counting. For the calculation of this index it is necessary only results of general analysis of blood. For greater simplification of calculation of index it is possible to use the personal computer with Ms Office software or calculator.

Keywords: children, acute appendicitis, endogenous intoxication, index.

Стаття надійшла в редакцію 23.04. 2020 р. 